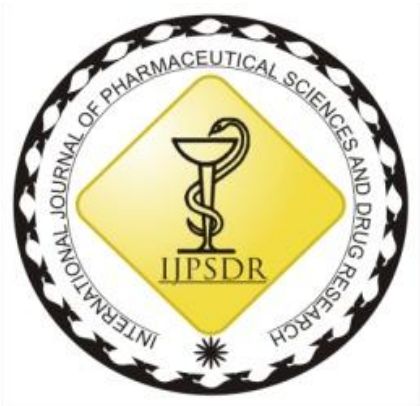

ISSN: 0975-248X

RESEARCH ARTICLE CODEN (USA): IJPSPP

$(\mathrm{cc})$ EY-NG-SA

\title{
Spectrophotometric Method Development and Validation for Simultaneous Estimation of Nebivolol hydrochloride and Valsartan in Bulk and Combined Pharmaceutical Dosage Form in Release Media
}

\author{
Chandani Makvana*, Satyajit Sahoo \\ Faculty of Pharmacy, C. U. Shah University, Surendranagar-Ahmedabad highway, Near Kothariya village, Dist. \\ Surendranagar, Wadhwan-363030, Gujarat, India
}

Copyright (C) 2019 Chandani Makvana et al. This is an open access article distributed under the terms of the Creative Commons AttributionNonCommercial-ShareAlike 4.0 International License which allows others to remix, tweak, and build upon the work non-commercially, as long as the author is credited and the new creations are licensed under the identical terms.

\begin{abstract}
A simple, rapid, precise, accurate and sensitive spectrophotometric method has been developed for the simultaneous estimation and validation of Nebivolol Hydrochloride (NEB) and Valsartan (VAL) in pure and combined tablet dosage forms. Pure drug samples of NEB and VAL were dissolved in $67 \mathrm{mM}$ Phosphate buffer pH 6.8 with $0.5 \%$ sodium dodecyl sulphate (SDS) and found to have absorbance maxima at $280 \mathrm{~nm}$ for NEB and $250 \mathrm{~nm}$ for VAL, respectively. The linearity lies between $10-70 \mu \mathrm{g} / \mathrm{ml}$ for NEB and $10-60 \mu \mathrm{g} / \mathrm{ml}$ for VAL in this method. The correlation coefficient (r2) was found to be 0.9965 for NEB and 0.9960 for VAL. The \% recoveries obtained were $95.65 \%$ $109.85 \%$ for NEB and $97.42 \%-101.43 \%$ for VAL. The $\%$ RSD found $0.271 \%-1.490 \%$ for intraday and $0.334 \%-1.917 \%$ for interday for NEB and $0.188 \%-0.944 \%$ for intraday and $0.392 \%-1.197 \%$ for interday for VAL. The limit of detection and limit of quantitation for NEB were found to be $4.608 \mu \mathrm{g} / \mathrm{ml}$ and $13.965 \mu \mathrm{g} / \mathrm{ml} \mathrm{respectively} \mathrm{and} \mathrm{the} \mathrm{limit}$ of detection and limit of quantitation for VAL were found to be $4.348 \mu \mathrm{g} / \mathrm{ml}$ and $13.178 \mu \mathrm{g} / \mathrm{ml}$ respectively. Simultaneous calibration of both drugs in $67 \mathrm{mM}$ Phosphate buffer $\mathrm{pH} 6.8$ with $0.5 \%$ SDS shows that $\lambda$ max of one drug does not interfere on the $\lambda$ max of other drug. Recovery study was performed to confirm the accuracy of the method. The results of analysis have been validated statistically by recovery studies as per International Conference on Harmonization guidelines. The method showed good reproducibility and recovery with $\%$ RSD $<2$. Hence, this proposed method was found to be rapid, specific, precise and accurate and can be successfully applied for the routine analysis of NEB and VAL in pure and combined tablet dosage form.
\end{abstract}

Keywords: Nebivolol hydrochloride, Valsartan, UV spectroscopy, Simultaneous equation method, Method development and validation.

\footnotetext{
*Corresponding author: Ms. Chandani Makvana

Address: Faculty of Pharmacy, C. U. Shah University, Surendranagar-Ahmedabad highway, Near Kothariya village, Dist. Surendranagar, Wadhwan363030, Gujarat, India

E-mail $\bowtie$ : chandani.makvana1991@gmail.com

Relevant conflicts of interest/financial disclosures: The authors declare that the research was conducted in the absence of any commercial or financial relationships that could be construed as a potential conflict of interest.

Received: 13 August, 2019; Revised: 16 October, 2019; Accepted: 25 October, 2019; Published: 30 November, 2019
}

\section{INTRODUCTION}

NEB is a highly cardioselective vasodilatory $\beta 1$ receptor blocker used in treatment of hypertension.
NEB is a selective $\beta 1$-receptor antagonist. Activation of a1-receptors by epinephrine increases the heart rate, blood pressure and the heart consumes more oxygen. 
NEB blocks these receptors which reverses the effects of epinephrine, lowering the heart rate and blood pressure. In addition, beta blockers prevent the release of renin, which is a hormone produced by the kidneys which leads to constriction of blood vessels. At high enough concentrations, this drug may also bind $\beta 2$ receptors. [1-3]

VAL is an Angiotensin receptor blocker that selectively inhibits the binding of angiotensin II to angiotensin I, which is found in many tissues such as vascular smooth muscle and the adrenal glands. This effectively inhibits the angiotensin I-mediated vasoconstrictive and aldosterone-secreting effects of angiotensin II and results in a decrease in vascular resistance and blood pressure. [4]

The majority of patients with hypertension require two or more medications to achieve their blood pressure goals. So, the fixed dose combination of NEB (5 mg) and VAL (80 mg) which was approved in June 06, 2016 by US FDA was selected that reduce blood pressure through multiple mechanism of action. It is first and only fixed dose combination of a beta blocker and angiotensin II receptor blocker available in US. [5] The addition of NEB counteracts the effect of increased angiotensin II concentrations resulting from potent AT1 blockage and give better anti-hypertensive effect than monotherapy effect. [6]

Different analytical methods have been reported in the literature for the assay of NEB and VAL in bulk and pharmaceuticals which include spectrophotometry, TLC, HPLC, HPTLC and LC-MS using different solvents. ${ }^{[7-28]}$ The present investigation reports a simple UV Spectrophotometric method for the analysis of NEB and VAL in bulk as well as in tablet dosage form using $67 \mathrm{mM}$ phosphate buffer $\mathrm{pH} 6.8$ with $0.5 \%$ SDS (finished dosage form release media) as a solvent for developing and proving the method. [29] The developed method was validated as per ICH guidelines Q2(R1) Validation of Analytical procedures: Text and methodology. [30-31]

\section{MATERIALS AND METHODS \\ Instrument}

A Shimadzu UV-visible spectrophotometer (Lab India, UV3092, 20-1950-21-0004) was employed with a spectral bandwidth of $2 \mathrm{~nm}$ and wavelength accuracy of $\pm 0.5 \mathrm{~nm}$ with automatic wavelength correction with a pair of $10 \mathrm{~mm}$ quartz cells.

\section{Chemicals and reagents}

An analytically pure sample of NEB and VAL were received as gift sample from Torrent research centre, Ahmedabad, India. All the chemicals used were of analytical grade.

Preparation of $67 \mathrm{mM}$ Phosphate buffer $\mathrm{pH} 6.8$ with $0.5 \%$ SDS: Accurately weighted $10.45 \mathrm{~g}$ Sodium dihydrogen orthophosphate $\left(\mathrm{NaH}_{2} \mathrm{PO}_{4}\right), 0.9 \mathrm{~g} \mathrm{NaOH}$ and $5 \mathrm{~g}$ SDS and dissolved in $1000 \mathrm{ml}$ Purified water. This solution was then used for further method development and validation study.
The commercial sample of Nebicard-V containing NEB $5 \mathrm{mg}$ and VAL $80 \mathrm{mg}$ was purchased from local market. Preparation of standard curve of NEB and VAL Preparation of standard stock solution $(1000 \mu \mathrm{g} / \mathrm{ml})$

The standard stock solutions of $1000 \mu \mathrm{g} / \mathrm{ml}$ of NEB and VAL were prepared separately. $100 \mathrm{mg}$ of both the drugs was separately taken in $100 \mathrm{ml}$ volumetric flask and dissolved in $67 \mathrm{mM}$ Phosphate buffer $\mathrm{pH} 6.8$ with $0.5 \%$ SDS and then volume made up to the mark with $67 \mathrm{mM}$ Phosphate buffer $\mathrm{pH} 6.8$ with $0.5 \%$ SDS to get a concentration of $1000 \mu \mathrm{g} / \mathrm{ml}$.

Preparation of working standard solution $(100 \mu \mathrm{g} / \mathrm{ml})$

The working standard solution of $100 \mu \mathrm{g} / \mathrm{ml}$ of NEB and VAL were prepared separately. $10 \mathrm{ml}$ standard stock solution of both drugs was separately transferred to a $100 \mathrm{ml}$ volumetric flask and volume was adjusted to $100 \mathrm{ml}$ with $67 \mathrm{mM}$ Phosphate buffer $\mathrm{pH} 6.8$ with 0.5 $\%$ SDS to get a concentration of $100 \mu \mathrm{g} / \mathrm{ml}$.

\section{Preparation of dilutions for calibration curve}

By appropriate dilution of working standard solution of NEB and VAL with $67 \mathrm{mM}$ Phosphate buffer $\mathrm{pH} 6.8$ with $0.5 \%$ SDS, solutions containing $10 \mu \mathrm{g} / \mathrm{ml}$ of NEB and $10 \mu \mathrm{g} / \mathrm{ml}$ of VAL were scanned separately in the range of $200 \mathrm{~nm}-400 \mathrm{~nm}$. Wavelength of maximum absorption was determined for both the drugs. NEB showed maximum absorbance at $280 \mathrm{~nm}$ and VAL at $250 \mathrm{~nm}$. These dilutions gave 10, 20, 30, 40, 50, 60 and $70 \mu \mathrm{g} / \mathrm{ml}$ concentration of NEB and 10, 20, 30, 40, 50 and $60 \mu \mathrm{g} / \mathrm{ml}$ concentration of VAL. The absorbance of prepared solutions of NEB and VAL in $67 \mathrm{mM}$ Phosphate buffer pH 6.8 with $0.5 \%$ SDS was measured at wavelength maximum $280 \mathrm{~nm}$ and $250 \mathrm{~nm}$ using Shimadzu UV-visible spectrophotometer against 67 $\mathrm{mM}$ Phosphate buffer $\mathrm{pH} 6.8$ with $0.5 \%$ SDS as blank. The experiment was performed in triplicate and based on average absorbance; the equation for the best line was generated. The results of standard curve preparation are shown in Table 1 and Fig. 1 for NEB and Table 2 and Fig. 2 for VAL.

Validation of Analytical method of NEB and VAL Analytical measurement of NEB and VAL in $67 \mathrm{mM}$ Phosphate buffer $\mathrm{pH} \quad 6.8$ with $0.5 \%$ SDS by UV spectrophotometry was validated separately as per ICH guideline, Q2(R1). The UV spectrophotometric method was validated for the quantification of NEB and VAL in samples. Intraday and Interday precision and accuracy were determined by analysis of five concentrations. The overall precision of the method was expressed as relative standard deviation (RSD) and the accuracy of the method was expressed in terms of relative error.

Linearity and range: Linearity is expressed in terms of correlation coefficient of linear regression analysis. The linearity response was determined by analyzing independent levels of calibration curve in the range of $10-70 \mu \mathrm{g} / \mathrm{ml}$ for NEB and $10-60 \mu \mathrm{g} / \mathrm{ml}$ for VAL. Plot the calibration curve of absorbance vs concentration and determines correlation coefficient and regression line equations for NEB and VAL separately. 
Accuracy preparation of sample solution: The accuracy study was determined by standard addition method. $100 \mathrm{mg}$ of NEB and VAL was weighed and transferred into a $100 \mathrm{ml}$ of volumetric flask, dissolved and diluted up to mark with $67 \mathrm{mM}$ Phosphate buffer $\mathrm{pH} 6.8$ with $0.5 \%$ SDS separately. Pipette out $10 \mathrm{ml}$ of the above solution in $100 \mathrm{ml}$ volumetric flask and diluted to mark with $67 \mathrm{mM}$ Phosphate buffer $\mathrm{pH} 6.8$ with $0.5 \%$ SDS to get $100 \mu \mathrm{g} / \mathrm{ml}$ solution of NEB and $\mathrm{VAL}$, from that $20 \mu \mathrm{g} / \mathrm{ml}$ of solution for NEB and $10 \mu \mathrm{g} / \mathrm{ml}$ of solution for VAL were prepared. To one $\mathrm{ml}$ of the above solution, increasing aliquots of standard solution $(10,20$ and $30 \mu \mathrm{g} / \mathrm{ml}$ of $\mathrm{NEB}, 5,10$ and $15 \mu \mathrm{g} / \mathrm{ml}$ of VAL) were added and diluted to $10 \mathrm{ml}$ with $67 \mathrm{mM}$ Phosphate buffer $\mathrm{pH} 6.8$ with $0.5 \%$ SDS. Absorbance of solution was measured at selected wavelength. The amount of NEB and VAL was calculated at each level and \% recoveries were computed.

\section{Precision}

Repeatability: The absorbance of same concentration was measured three times and RSD was calculated.

Intraday Precision: Solutions containing 10-70 $\mu \mathrm{g} / \mathrm{ml}$ of NEB and $10-60 \mu \mathrm{g} / \mathrm{ml}$ of VAL were analyzed three times on the same day and \% RSD was calculated.

Interday Precision: Solutions containing 10-70 $\mu \mathrm{g} / \mathrm{ml}$ of $\mathrm{NEB}$ and $10-60 \mu \mathrm{g} / \mathrm{ml}$ of VAL were analyzed three times on the different 3 days and \% RSD was calculated. It is a measure of either the degree of reproducibility or repeatability of the analytical method.

Limit of detection (LOD) and Limit of quantitation (LOQ): The limit of detection (LOD) is the lowest amount of analyte in a sample that can be detected, but not necessarily quantified, under standard experimental condition. The limit of quantification (LOQ) is the lowest amount of analyte in a sample that can be determined with acceptable precision and accuracy under standard experimental condition. LOD and LOQ were calculated using the following formula:

$$
\begin{aligned}
& \mathrm{LOD}=3.3 \sigma / \mathrm{S} \\
& \mathrm{LOQ}=10 \mathrm{\sigma} / \mathrm{S}
\end{aligned}
$$

Where $\sigma$ is Standard deviation of the response and $S$ is slope of the calibration curve.

\section{Simultaneous estimation of NEB and VAL}

\section{Preparation of standard stock solution}

Stock solutions $(1000 \mu \mathrm{g} / \mathrm{ml})$ of NEB and VAL were prepared by dissolving separately $100 \mathrm{mg}$ of drug in 67 $\mathrm{mM}$ Phosphate buffer $\mathrm{pH} 6.8$ with $0.5 \%$ SDS. Than make up the volume with $67 \mathrm{mM}$ Phosphate buffer $\mathrm{pH}$ 6.8 with $0.5 \%$ SDS. The stock solution were suitably diluted to produce solution of concentration $100 \mu \mathrm{g} / \mathrm{ml}$, these working standard solutions were scanned in the entire UV range $(200 \mathrm{~nm}-400 \mathrm{~nm})$ to determine the $\lambda$ max. Absorption maxima of NEB and VAL were detected at $280 \mathrm{~nm}(\lambda 2)$ and $250 \mathrm{~nm}(\lambda 1)$, respectively and overlain spectra was recorded. A series of standard dilutions of each drug were prepared having concentration range of $10-70 \mu \mathrm{g} / \mathrm{ml}$. NEB and VAL showed linearity with absorbance in the range 10$70 \mu \mathrm{g} / \mathrm{ml}$ and $10-60 \mu \mathrm{g} / \mathrm{ml}$ respectively. The absorbances were measured at $250 \mathrm{~nm}$ and $280 \mathrm{~nm}$ and calibration curves were plotted at these wavelengths.

Simultaneous equations method

Method is based on simultaneous equations method of Vierodt. Absorption maxima of NEB and VAL were 280 $\mathrm{nm}(\lambda 2)$ and $250 \mathrm{~nm}(\lambda 1)$, respectively. Calibration curve for NEB and VAL was prepared in the concentration range $10-70 \mu \mathrm{g} / \mathrm{ml}$ and $10-60 \mu \mathrm{g} / \mathrm{ml}$ respectively. The absorptivity coefficients of the two drugs were determined by using Beer's law: A = E (1\%, $1 \mathrm{~cm}) \mathrm{CL}$ and their average value taken. The overlain spectra of NEB and VAL are represented in [Fig. 3]. A set of two simultaneous equations was developed using these absorptivity coefficients. These are: A1 $=0.03372$ $\mathrm{Cx}+0.0011 \mathrm{Cy} \ldots(1) ;$ and A2 $=0.0074 \mathrm{Cx}+0.0156$ Cy...(2), where A1 and A2 are absorbances at $250 \mathrm{~nm}$ and $280 \mathrm{~nm}$ respectively, and Cx and Cy are concentrations of VAL and NEB respectively.

Analysis of tablet formulation

For the estimation of drugs in the commercial formulations, 20 tablets containing $5 \mathrm{mg}$ of NEB and 80 $\mathrm{mg}$ of VAL were weighed and average weight was calculated. The tablets were crushed and powdered in a glass mortar. For the analysis of drugs, quantity of powder equivalent to $5 \mathrm{mg}$ of NEB and $80 \mathrm{mg}$ of VAL was transferred to $100 \mathrm{ml}$ volumetric flasks and dissolved in sufficient quantity of $67 \mathrm{mM}$ Phosphate buffer pH 6.8 with $0.5 \%$ SDS. It was sonicated for 30 minutes and volume was made up to the mark to obtain a stock solution of $1000 \mu \mathrm{g} / \mathrm{ml}$ of $\mathrm{NEB}$ and $1000 \mu \mathrm{g} / \mathrm{ml}$ of VAL. This solution was then filtered through whatman filter paper (grade one). Further dilutions were made from this stock solution to get required concentration.

\section{RESULTS AND DISCUSSION}

The optimized UV method for Simultaneous estimation was validated according to the procedures described in ICH guidelines Q2 (R1) for the validation of analytical method.

\section{Preparation of standard curve of NEB and VAL}

The drug was scanned in wavelength range of $200 \mathrm{~nm}$ $800 \mathrm{~nm}$ by UV double beam spectrophotometer to determine the absorption maxima. The absorption maxima found to beat wavelength of $280 \mathrm{~nm}$ and 250 $\mathrm{nm}$ for NEB and VAL in $67 \mathrm{mM}$ Phosphate buffer $\mathrm{pH}$ 6.8 with $0.5 \%$ SDS respectively.

NEB and VAL in the concentration of $10 \mu \mathrm{g} / \mathrm{ml}$ in 67 $\mathrm{mM}$ Phosphate buffer $\mathrm{pH} 6.8$ with $0.5 \%$ SDS scanned in the UV region of $200 \mathrm{~nm}-800 \mathrm{~nm}$ showed absorption maxima of $280 \mathrm{~nm}$ for NEB and $250 \mathrm{~nm}$ for VAL using $67 \mathrm{mM}$ Phosphate buffer $\mathrm{pH} 6.8$ with $0.5 \%$ SDS as blank. This confirmed the authenticity of the sample. Therefore, the wavelength of $280 \mathrm{~nm}$ and $250 \mathrm{~nm}$ were used for the quantitative estimation of NEB and VAL respectively. 
NEB and VAL exhibits maximum absorbance at $280 \mathrm{~nm}$ and $250 \mathrm{~nm}$ respectively and obeyed Beer's law in the range of $10-70 \mu \mathrm{g} / \mathrm{ml}$ and $10-60 \mu \mathrm{g} / \mathrm{ml}$ respectively. The results of calibration curve preparation were showed in Table 1 and Fig. 1 for NEB and Table 2 and Fig. 2 for VAL.

Table 1: Standard calibration curve data of NEB

\begin{tabular}{cccccc}
\hline $\begin{array}{c}\text { S. } \\
\text { No. }\end{array}$ & $\begin{array}{c}\text { Concentration } \\
(\boldsymbol{\mu} \mathrm{g} / \mathrm{ml})\end{array}$ & \multicolumn{3}{c}{ Absorbance } & $\begin{array}{c}\text { Absorbance } \\
(\text { Mean* } \pm \text { SD) }\end{array}$ \\
\hline 1 & 10 & 0.139 & 0.141 & 0.14 & $0.140 \pm 0.001$ \\
2 & 20 & 0.281 & 0.283 & 0.284 & $0.283 \pm 0.0015$ \\
3 & 30 & 0.396 & 0.392 & 0.395 & $0.394 \pm 0.0021$ \\
4 & 40 & 0.592 & 0.593 & 0.59 & $0.592 \pm 0.0015$ \\
5 & 50 & 0.756 & 0.755 & 0.756 & $0.756 \pm 0.0005$ \\
6 & 60 & 0.923 & 0.924 & 0.921 & $0.923 \pm 0.0015$ \\
7 & 70 & 1.059 & 1.062 & 1.06 & $1.060 \pm 0.0015$ \\
\hline
\end{tabular}

SD: Standard deviation, ${ }^{*}$ : Mean of each 3 reading

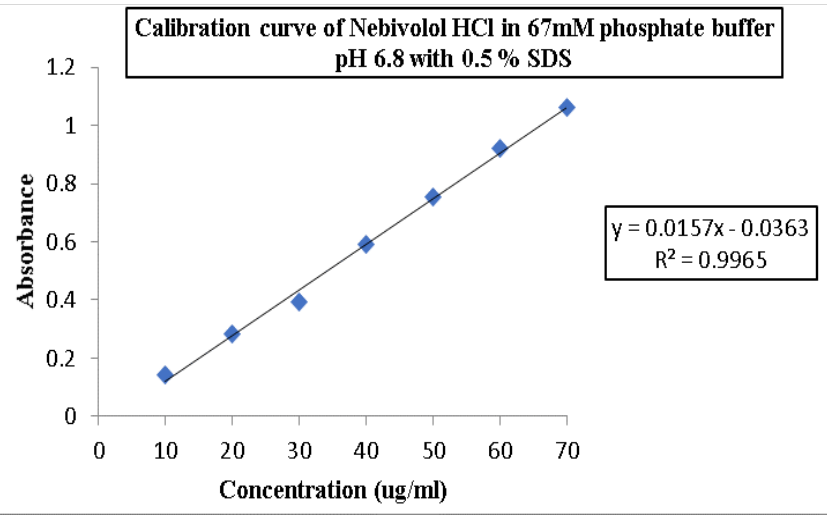

Fig. 1: Standard calibration curve of NEB

Table 2: Standard calibration curve data of VAL

\begin{tabular}{cccccc}
\hline $\begin{array}{c}\text { S. } \\
\text { No. }\end{array}$ & $\begin{array}{c}\text { Concentration } \\
(\mu \mathrm{g} / \mathrm{ml})\end{array}$ & \multicolumn{3}{c}{ Absorbance } & $\begin{array}{c}\text { Absorbance } \\
\left(\mathbf{M e a n}^{*} \pm \mathrm{SD}\right)\end{array}$ \\
\hline 1 & 10 & 0.220 & 0.221 & 0.219 & $0.220 \pm 0.001$ \\
2 & 20 & 0.352 & 0.35 & 0.351 & $0.351 \pm 0.001$ \\
3 & 30 & 0.509 & 0.511 & 0.509 & $0.509 \pm 0.0011$ \\
4 & 40 & 0.662 & 0.660 & 0.663 & $0.662 \pm 0.0015$ \\
5 & 50 & 0.817 & 0.818 & 0.815 & $0.817 \pm 0.0015$ \\
6 & 60 & 1.023 & 1.019 & 1.020 & $1.020 \pm 0.0021$ \\
\hline
\end{tabular}

SD: Standard deviation, ${ }^{*}$ : Mean of each 3 reading

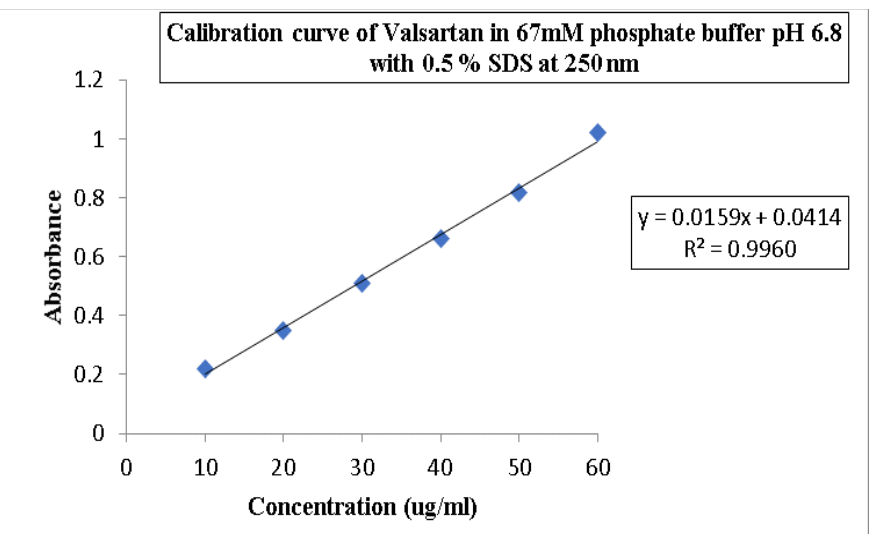

Fig. 2: Standard calibration curve of VAL

Validation of Analytical method of NEB and VAL Linearity and range

The linearity of measurement was evaluated by analyzing different concentrations of the standard solution of NEB and VAL. The data obtained in the calibration experiments when subjected to linear regression analysis showed a linear relationship between absorbance and concentrations in the range 10 $70 \mu \mathrm{g} / \mathrm{ml}$ for NEB and $10-60 \mu \mathrm{g} / \mathrm{ml}$ for VAL. The results of calibration curve preparation were showed in Table 1 and Table 2 for NEB and VAL respectively. The respective linear equation for NEB was $y=0.0157 x-$ 0.0363 and VAL equation $y=0.0159 x+0.0414$, where $x$ is the concentration and $y$ is the absorbance. The correlation coefficient was found to be 0.9965 at $280 \mathrm{~nm}$ and 0.9960 at $250 \mathrm{~nm}$ for NEB and VAL respectively. The calibration curve of NEB and VAL is depicted in Fig. 1 and Fig. 2.

Accuracy (\% recovery)

To ascertain the accuracy of proposed methods, recovery studies were carried out by standard addition method. To pre analyzed tablet solution, a definite concentration of standard drug (50\%, 100\% and 150\%) was added and then its recovery was analyzed. The $\%$ recoveries were found to be within $95.65 \%-109.85 \%$ and $97.42 \%-101.43 \%$ for NEB and VAL respectively. The results of recovery study were showed in Table 3 and Table 4 for NEB and VAL respectively.

Table 3: Data of recovery study for NEB

\begin{tabular}{cccccc}
\hline S. & $\begin{array}{c}\text { Amount of } \\
\text { drug } \\
\text { taken }(\boldsymbol{\mu g} / \mathbf{m l})\end{array}$ & $\begin{array}{c}\text { Amount } \\
\text { of drug } \\
\text { added } \\
(\boldsymbol{\mu} \mathbf{g} / \mathbf{m l})\end{array}$ & $\begin{array}{c}\text { Total } \\
\text { amount } \\
\text { of drug } \\
(\boldsymbol{\mu} \mathbf{g} / \mathbf{m l})\end{array}$ & $\begin{array}{c}\text { Amount } \\
\text { of drug } \\
\text { found } \\
(\boldsymbol{\mu} \mathbf{g} / \mathbf{m l})\end{array}$ & $\begin{array}{c}\% \\
\text { Recovery }\end{array}$ \\
\hline 1 & 20 & - & 20 & - & - \\
2 & 20 & 10 & 30 & 28.69 & 95.65 \\
3 & 20 & 20 & 40 & 42.39 & 105.97 \\
4 & 20 & 30 & 50 & 54.92 & 109.85 \\
\hline
\end{tabular}

\begin{tabular}{cccccc}
\multicolumn{5}{c}{ Table 4: Data of recovery study for VAL } \\
\hline $\begin{array}{c}\text { S. } \\
\text { No }\end{array}$ & $\begin{array}{c}\text { Amount of } \\
\text { drug } \\
\text { taken }(\boldsymbol{\mu} \mathbf{g} / \mathbf{m l})\end{array}$ & $\begin{array}{c}\text { Amount } \\
\text { of drug } \\
\text { added } \\
(\boldsymbol{\mu g} / \mathbf{m l})\end{array}$ & $\begin{array}{c}\text { Total } \\
\text { amount } \\
\text { of drug } \\
(\boldsymbol{\mu g} / \mathbf{m l})\end{array}$ & $\begin{array}{c}\text { Amount } \\
\text { of drug } \\
\text { found } \\
(\boldsymbol{\mu g} / \mathbf{m l})\end{array}$ & $\begin{array}{c}\% \\
\text { Recovery }\end{array}$ \\
\hline 1 & 20 & - & 20 & - & - \\
2 & 20 & 10 & 30 & 29.22 & 97.42 \\
3 & 20 & 20 & 40 & 39.14 & 97.85 \\
4 & 20 & 30 & 50 & 50.71 & 101.43 \\
\hline
\end{tabular}

\section{Precision}

The precision UV methods was obtained by analyze on the same day (intra-day) and analyze on the different days by triplicate analysis (inter-day) and expressed as relative standard deviation percentage. For NEB the $\%$ RSD found $0.271 \%-1.490 \%$ for intraday and $0.334 \%$ $1.917 \%$ for interday. For VAL the \% RSD found 0.188 $\%-0.944 \%$ for intraday and $0.392 \%-1.197 \%$ for interday. Precision revealed that the proposed method is precise. Results were showed in Table 5 and Table 6 for NEB and Table 7 and Table 8 for VAL.

Limit of detection (LOD) and Limit of quantitation (LOQ)

LOD and LOQ were performed on samples containing concentration of analytes, based on the standard deviation of the response and the slope of calibration curve. The slope and standard deviation (SD) values were calculated using the linearity graph. The LOD was 
found $4.608 \mu \mathrm{g} / \mathrm{ml}$ and $4.348 \mu \mathrm{g} / \mathrm{ml}$ for NEB and VAL respectively. The LOQ was found $4.608 \mu \mathrm{g} / \mathrm{ml}$ and $4.348 \mu \mathrm{g} / \mathrm{ml}$ for NEB and VAL respectively.

Table 5: Intraday precision data for NEB

\begin{tabular}{|c|c|c|c|c|c|c|}
\hline \multirow{2}{*}{$\begin{array}{l}\text { S. } \\
\text { No }\end{array}$} & \multirow{2}{*}{$\begin{array}{c}\text { Concentration } \\
(\mu \mathrm{g} / \mathrm{ml})\end{array}$} & \multicolumn{3}{|c|}{ Absorbance } & \multirow{2}{*}{$\begin{array}{c}\text { Absorbance } \\
\left(\text { Mean }^{*} \pm \text { SD) }\right.\end{array}$} & \multirow{2}{*}{$\begin{array}{c}\% \\
\text { RSD }\end{array}$} \\
\hline & & 1 & 2 & 3 & & \\
\hline 1 & 10 & 0.142 & 0.138 & 0.139 & $0.140 \pm 0.0020$ & 1.490 \\
\hline 2 & 20 & 0.278 & 0.279 & 0.281 & $0.279 \pm 0.0015$ & 0.546 \\
\hline 3 & 30 & 0.391 & 0.395 & 0.393 & $0.393 \pm 0.002$ & 0.508 \\
\hline 4 & 40 & 0.591 & 0.589 & 0.587 & $0.589 \pm 0.002$ & 0.339 \\
\hline 5 & 50 & 0.752 & 0.75 & 0.755 & $0.752 \pm 0.0025$ & 0.334 \\
\hline 6 & 60 & 0.926 & 0.928 & 0.931 & $0.928 \pm 0.0025$ & 0.271 \\
\hline 7 & 70 & 1.061 & 1.054 & 1.055 & $1.056 \pm 0.0037$ & 0.358 \\
\hline
\end{tabular}

SD: Standard deviation, RSD: Relative standard deviation, * : Mean of each 3 reading

Table 6: Interday precision data for NEB

\begin{tabular}{|c|c|c|c|c|c|c|}
\hline \multirow{2}{*}{$\begin{array}{l}\text { S. } \\
\text { No }\end{array}$} & \multirow{2}{*}{$\begin{array}{c}\text { Concentration } \\
(\mu \mathrm{g} / \mathrm{ml})\end{array}$} & \multicolumn{3}{|c|}{ Absorbance } & \multirow{2}{*}{$\begin{array}{c}\text { Absorbance } \\
\left(\text { Mean }^{*} \pm \text { SD) }\right.\end{array}$} & \multirow{2}{*}{$\begin{array}{c}\% \\
\text { RSD }\end{array}$} \\
\hline & & 1 & 2 & 3 & & \\
\hline 1 & 10 & 0.137 & 0.141 & 0.136 & $0.138 \pm 0.0026$ & 1.917 \\
\hline 2 & 20 & 0.281 & 0.28 & 0.28 & $0.280 \pm 0.0005$ & 0.205 \\
\hline 3 & 30 & 0.389 & 0.391 & 0.394 & $0.391 \pm 0.0025$ & 0.643 \\
\hline 4 & 40 & 0.585 & 0.589 & 0.593 & $0.5894 \pm 0.004$ & 0.679 \\
\hline 5 & 50 & 0.751 & 0.749 & 0.754 & $0.751 \pm 0.0025$ & 0.334 \\
\hline 6 & 60 & 0.92 & 0.926 & 0.921 & $0.922 \pm 0.0035$ & 0.348 \\
\hline 7 & 70 & 1.058 & 1.067 & 1.065 & $1.063 \pm 0.0047$ & 0.444 \\
\hline
\end{tabular}

SD: Standard deviation, RSD: Relative standard deviation, * : Mean of each 3 reading

Table 7: Intraday precision data for VAL

\begin{tabular}{|c|c|c|c|c|c|c|}
\hline \multirow{2}{*}{$\begin{array}{l}\text { S. } \\
\text { No }\end{array}$} & \multirow{2}{*}{$\begin{array}{c}\text { Concentration } \\
(\mu \mathrm{g} / \mathrm{ml})\end{array}$} & \multicolumn{3}{|c|}{ Absorbance } & \multirow{2}{*}{$\begin{array}{c}\text { Absorbance } \\
(\text { Mean* } \pm \text { SD) }\end{array}$} & \multirow{2}{*}{$\begin{array}{c}\% \\
\text { RSD } \\
\end{array}$} \\
\hline & & 1 & 2 & 3 & & \\
\hline 1 & 10 & 0.222 & 0.221 & 0.218 & $0.220 \pm 0.0021$ & 0.944 \\
\hline 2 & 20 & 0.348 & 0.349 & 0.351 & $0.349 \pm 0.0015$ & 0.437 \\
\hline 3 & 30 & 0.512 & 0.513 & 0.509 & $0.511 \pm 0.0021$ & 0.407 \\
\hline 4 & 40 & 0.665 & 0.660 & 0.661 & $0.662 \pm 0.0026$ & 0.399 \\
\hline 5 & 50 & 0.810 & 0.809 & 0.812 & $0.810 \pm 0.0015$ & 0.188 \\
\hline 6 & 60 & 1.031 & 1.029 & 1.034 & $1.031 \pm 0.0025$ & 0.244 \\
\hline
\end{tabular}

SD: Standard deviation, RSD: Relative standard deviation, * : Mean of each 3 reading

Table 8: Interday precision data for VAL

\begin{tabular}{|c|c|c|c|c|c|c|}
\hline \multirow{2}{*}{$\begin{array}{l}\text { S. } \\
\text { No }\end{array}$} & \multirow{2}{*}{$\begin{array}{c}\text { Concentration } \\
(\mu \mathrm{g} / \mathrm{ml})\end{array}$} & \multicolumn{3}{|c|}{ Absorbance } & \multirow{2}{*}{$\begin{array}{c}\text { Absorbance } \\
\left(\text { Mean }^{*} \text { SD) }\right.\end{array}$} & \multirow{2}{*}{$\begin{array}{c}\% \\
\text { RSD }\end{array}$} \\
\hline & & 1 & 2 & 3 & & \\
\hline 1 & 10 & 0.219 & 0.224 & 0.22 & $0.221 \pm 0.0026$ & 1.197 \\
\hline 2 & 20 & 0.345 & 0.348 & 0.347 & $0.347 \pm 0.0015$ & 0.440 \\
\hline 3 & 30 & 0.51 & 0.508 & 0.512 & $0.510 \pm 0.002$ & 0.392 \\
\hline 4 & 40 & 0.66 & 0.664 & 0.669 & $0.664 \pm 0.0045$ & 0.678 \\
\hline 5 & 50 & 0.815 & 0.821 & 0.811 & $0.816 \pm 0.0050$ & 0.617 \\
\hline 6 & 60 & 1.022 & 1.029 & 1.032 & $1.027 \pm 0.0051$ & 0.499 \\
\hline
\end{tabular}

SD: Standard deviation, RSD: Relative standard deviation, * : Mean of each 3 reading

\section{Summary of Validation Parameters}

The proposed method was found to be linear over concentration range of $10-70 \mu \mathrm{g} / \mathrm{ml}$ and $10-60 \mu \mathrm{g} / \mathrm{ml}$ for NEB and VAL respectively. The method was found to be accurate and precise as indicated by the results of recovery studies and precision studies whose \% RSD is not more than $2 \%$. The results of the analysis of NEB and VAL by the proposed method were highly reproducible and reliable which conclude that the proposed method is highly simple, sensitive, reproducible, economic, less time consuming and easy to apply for routine analysis of NEB and VAL in $67 \mathrm{mM}$ Phosphate buffer $\mathrm{pH} 6.8$ with $0.5 \%$ SDS.

Simultaneous estimation of NEB and VAL
The method was validated according to International Conference on Harmonization guidelines for validation of analytical procedures.

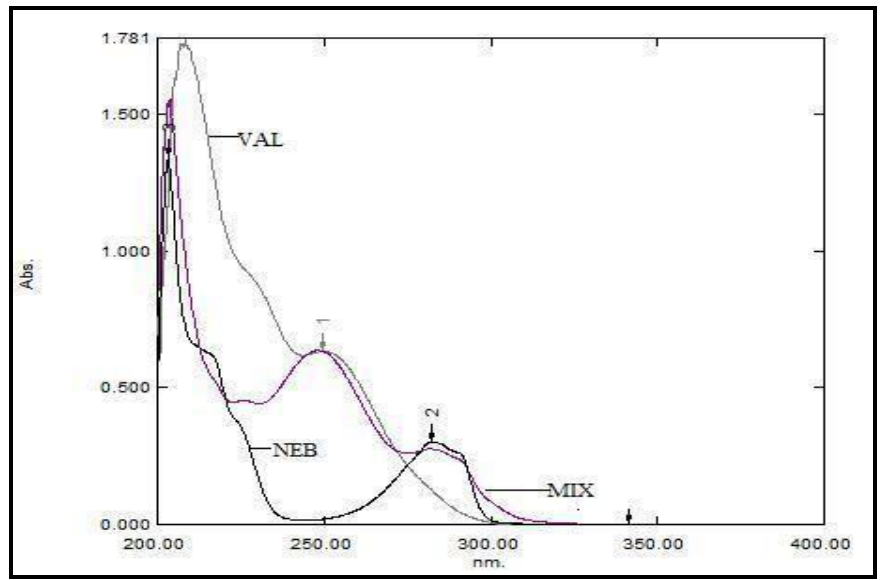

Fig. 3: The overlain spectra of NEB and VAL

Table 9: Summary of validation parameters of NEB and VAL

\begin{tabular}{|c|c|c|c|}
\hline \multirow{2}{*}{$\begin{array}{l}\text { S. } \\
\text { No }\end{array}$} & \multirow{2}{*}{$\begin{array}{l}\text { Validation } \\
\text { parameters }\end{array}$} & \multicolumn{2}{|c|}{ Results } \\
\hline & & NEB & VAL \\
\hline 1 & $\begin{array}{l}\text { Absorption maxima } \\
(\mathrm{nm})\end{array}$ & 280 & 250 \\
\hline 2 & $\begin{array}{l}\text { Linearity range } \\
\qquad(\mu \mathrm{g} / \mathrm{ml})\end{array}$ & $10-70$ & $10-60$ \\
\hline 3 & $\begin{array}{c}\text { Linearity equation } \\
\text { Linearity }\end{array}$ & $y=0.0157 x+0.0363$ & $y=0.0159 x+0.0414$ \\
\hline 4 & $\begin{array}{l}\text { (R2, Correlation } \\
\text { coefficient) }\end{array}$ & 0.9965 & 0.9960 \\
\hline 5 & Precision Intraday & $0.271 \%-1.490 \%$ & $0.188 \%-0.944 \%$ \\
\hline 5 & (\% RSD) & $0.334 \%-1.917 \%$ & $0.392 \%-1.197 \%$ \\
\hline 6 & $\begin{array}{c}\text { Accuracy (\% } \\
\text { Recovery) }\end{array}$ & $95.65 \%-109.85 \%$ & $97.42 \%-101.43 \%$ \\
\hline 7 & $\mathrm{LOD}(\mu \mathrm{g} / \mathrm{ml})$ & 4.608 & 4.348 \\
\hline 8 & $\mathrm{LOQ}(\mu \mathrm{g} / \mathrm{ml})$ & 13.965 & 13.178 \\
\hline
\end{tabular}

RSD: Relative standard deviation, LOD: Limit of detection, LOQ: Limit of quantification

Table 10: Accuracy and Precision data for determination of NEB and VAL

Accuracy and Precision data for determination of VAL in the presence of NEB

\begin{tabular}{ccc}
\hline $\begin{array}{c}\text { Added amount } \\
\text { of VAL (ug/ml) }\end{array}$ & $\begin{array}{c}\text { Within day } \\
\text { * } \\
\text { (Amount found } \pm \text { SD) }\end{array}$ & $\begin{array}{c}\text { Between day } \\
\text { * } \\
\text { (Amount found } \pm \text { SD) }\end{array}$ \\
\hline 10 & $10.05 \pm 0.04$ & $10.08 \pm 0.05$ \\
20 & $20.02 \pm 0.02$ & $20.13 \pm 0.11$ \\
30 & $30.16 \pm 0.21$ & $30.22 \pm 0.18$ \\
\hline
\end{tabular}

Accuracy and Precision data for determination of NEB in the presence of VAL

\begin{tabular}{ccc} 
& presence of VAL & \\
\hline $\begin{array}{c}\text { Added amount of } \\
\text { NEB (ug/ml) }\end{array}$ & $\begin{array}{c}\text { Within day * } \\
\text { (Amount found } \pm \\
\text { SD) }\end{array}$ & $\begin{array}{c}\text { Between day * } \\
\text { (Amount found } \pm \\
\text { SD) }\end{array}$ \\
\hline 2 & $2.05 \pm 0.06$ & $2.03 \pm 0.18$ \\
4 & $4.06 \pm 0.15$ & $4.10 \pm 0.03$ \\
6 & $6.07 \pm 0.12$ & $6.15 \pm 0.04$
\end{tabular}

SD: Standard deviation, ${ }^{*}$ : Mean of each 6 reading

Table 11: Assay results of NEB and VAL in Nebicard-V tablet

\begin{tabular}{|c|c|c|c|}
\hline \multirow{2}{*}{ Drugs } & \multicolumn{2}{|c|}{ Amount (mg/tablet) } & \multirow{2}{*}{$\begin{array}{c}\% \text { Label claim } \\
(\% \text { Found } \pm S D)\end{array}$} \\
\hline & Labelled (mg) & Found (Mean \pm SD) & \\
\hline NEB & $5 \mathrm{mg}$ & $4.98 \pm 0.06$ & $99.6 \pm 0.92$ \\
\hline VAL & $80 \mathrm{mg}$ & $79.96 \pm 0.24$ & $99.7 \pm 1.16$ \\
\hline
\end{tabular}

SD: Standard deviation, ${ }^{*}$ : Mean of each 6 reading

The results of the analysis of both drugs by the proposed method are highly reproducible and reliable. 
This UV spectrophotometric method was adopted for determination of the NEB and VAL release in the dissolution medium for in vitro dissolution testing of the combined dosage form. Simultaneous calibration of both drugs in $67 \mathrm{mM}$ Phosphate buffer $\mathrm{pH} 6.8$ with 0.5 $\%$ SDS shows that $\lambda$ max of one drug does not interfere on the $\lambda$ max of other drug. The developed method was found to be simple, sensitive, accurate and reproducible and can be used for routine analysis of NEB and VAL.

\section{ACKNOWLEDGEMENT}

The author expresses their gratitude to Torrent research centre, Ahmedabad, India for Gift samples of pure drugs.

\section{REFERENCES}

1. Thomas M, Tomasso G. Nebivolol: The Somewhat-Different Adrenergic Receptor Blocker. JACC 2009; 16:1491-99.

2. Olga H, Danielle E. Nebivolol (Bystolic), a Novel Beta Blocker for Hypertension. P.T. 2009;34:188-92.

3. https://www.drugbank.ca/drugs/DB04861

4. https://www.drugbank.ca/drugs/DB00177

5. https://www.allergan.com/news/news/thomsonreuters/allergan-announces-fda approval-of-byvalson-nebiv

6. https://www.ncbi.nlm.nih.gov/pubmed/20026768

7. Shah DA, Bhatt KK, Mehta RS, Baldania SL. Determination of Nebivolol Hydrochloride and Hydrochlorothiazide in Tablets by First-Order Derivative Spectrophotometry and Liquid Chromatography. JAOAC Int. 2008; 5:1075-82.

8. Kachhadia PK, Doshi AS, Joshi HS. Development and validation of a stability-indicating column high-performance liquid chromatographic assay method for determination of Nebivolol in tablet formulation. JAOAC Int. 2008; 91:557-61.

9. Kamila MM, Mondal N, Ghosh LK, Gupta BK. A validated UV spectrophotometric method for estimation of Nebivolol hydrochloride in bulk and pharmaceutical formulation. Pharmazie 2007;62:486-87.

10. Rajeswari KR, Sankar GG, Rao AL, Raju DB, Seshagiri R. RPHPLC Method for the Estimation of Nebivolol in Bulk and Pharmaceutical Dosage Form. Asian. J. Chem 2005;17:125963.

11. Sahoo MK, Giri RK, Barik CS, Kanungo SK, Ravi Kumar BV. RP-HPLC Method for the Estimation of Nebivolol in Tablet Dosage Form. E-Journal of Chem. 2009; 6:915-19.

12. Reddy TS, Devi PS. Validation of a high-performance thinlayer chromatographic method, with densitometric detection, for quantitative analysis of Nebivolol hydrochloride in tablet formulations. JPC 2007; 20:149-52.

13. Ramakrishna NV, Vishwottam KN, Koteshwara M, Manoj S, Santosh M, Varma DP. Rapid quantification of Nebivolol in human plasma by liquid chromatography coupled with electrospray ionization tandem mass spectrometry. J Pharm. Biomed. Anal. 2005; 39:1006-13.

14. Kokil SU, Bhatia MS. Simultaneous Estimation of Nebivolol Hydrochloride and Valsartan Using RP-HPLC. Indian J Pharm Sci 2009;71:111-14.
15. Arunadevi SB, Subramania NM, Suresh B. Simultaneous Determination of Nebivolol $\mathrm{HCl}$ and Valsartan in Solid Dosage Form by Spectrophotometric and RP-HPLC Method. IJPSR 2011;2:424-31.

16. Shinde SR, Bhoir SI, Pawar NS, Yadav SB, Ghumatkar AS, Bhagwat AM. Simultaneous Determination of Valsartan and Nebivolol $\mathrm{HCl}$ in Tablet Dosage Form by RP-HPLC. AJRC 2009;2:519-22.

17. Meyyanathan SN, Arunadevi SB, Bhojraj S. Simultaneous Estimation of Nebivolol Hydrochloride and Valsartan and Nebivolol Hydrochloride and Hydrochlorothiazide in Pharmaceutical Formulation by UV Spectrophotometric Methods. Indian J. Pharm. Educ. Res. 2010; 44:156-59.

18. Ediga SG, Krishna R. RP-HPLC Validation of Related Substances of Nebivolol in bulk and 2.5/5/10/20mg Tablets. IJPBCS 2012;1:11-21.

19. Koseki N, Kawashita H, Hara H, Niina M, Tanaka M, Kawai R. Development and Validation of a Method for Quantitative Determination of Valsartan in Human Plasma by Liquid Chromatography Tandem mass spectrometry. J Pharm Biomed Anal 2007;43:1769-74.

20. Patel SA, Patel HM. Development and Validation of HPTLC Method for Simultaneous Estimation of Nebivolol and Hydrochlorthiazide in Tablet. IJPFR 2012;2:28-38.

21. Sridevi R, Badal KM, Sameer GN. Simultaneous Spectrophotometric Determination of Valsartan and Ezetimibe in Pharmaceuticals. Trop J Pharm Res 2011;10:809. 15.

22. Macek J, Klima J, Ptacek P. Rapid Determination of Valsartan in human plasma by protein precipitation and HPLC. J Chromatogr B Analyt Technol Biomed Life Sci 2006;832:16972.

23. Madhavi C, Siddartha B, Parthiban C. Simultaneous estimation and validation of Nebivolol and Valsartan in tablet dosage form by RP-HPLC. Int J Pharm Sci;6:278-82.

24. Vaibhav S, Sufiyan A, Shastry VM, Yogesh P, Ansari S. Analytical method development and validation for the simultaneous estimation of Nebivolol and Valsartan by RPHPLC in bulk and tablet dosage forms. JPR 2017;11:472-78.

25. Kalpana N, Shanmukha KJ, Ramachandran D, Ganji R, Ganta S. Method Development and Validation of Stability Indicating RP-HPLC Method for Simultaneous Estimation of Nebivolol $\mathrm{HCl}$ and Valsartan in Bulk and its Pharmaceutical Formulations. AJADD 2014;2:624-37.

26. Sreelatha D, Ramya R, Ramarao T. Development and validation of RP-HPLC method for the simultaneous estimation of Nebivolol and Valsartan in pure bulk and pharmaceutical dosage form. Int J Pharm 2015;5:541-46.

27. Tripti S, Sudam CS. A validated gradient stability-indicating LC method for the analysis of Valsartan in pharmaceutical dosage form. Int J Pharm Pharm Sci 2016;8:128-33.

28. Aruna G, Bharathi K, Prasad K. Development and validation of bioanalytical HPLC method for simultaneous estimation of Cilnidipine and Nebivolol in human plasma. Int J Pharm Pharm Sci 2017;9:253-59.

29. https://www.accessdata.fda.gov/scripts/cder/dissolution/ dsp_SearchResults.cfm

30. Klaus Florey: Analytical profiles of drug substances. 64th ed. Elsevier Academic press; 2005. p.327-44.

31. Validation of Analytical Procedure, Text and Methodology. International Conference on Harmonisation ICH Q2 (R1); 2005 .

HOW TO CITE THIS ARTICLE: Makvana C, Sahoo S. Spectrophotometric Method Development and Validation for Simultaneous Estimation of Nebivolol hydrochloride and Valsartan in Bulk and Combined Pharmaceutical Dosage Form in Release Media. Int. J. Pharm. Sci. Drug Res. 2019; 11(6): 299-304. DOI: 10.25004/IJPSDR.2019.110604 